ANALISIS BELANJA LANGSUNG DAN PELAPORANNYA PADA DINAS KESEHATAN KABUPATEN TEMANGGUNG

\title{
Faridatul Jazilah
}

Universitas Tidar

Email: faridatuljazilah08@gmail.com

\section{Endang Kartini Panggiarti}

Universitas Tidar

Email: endangkartini2504@gmail.com

\begin{abstract}
The purpose of this study is to analyze direct expenditure and reporting to the Health Office. The data used is secondary data. Data collection techniques using documentation in the form of financial statements of the Health Office. The method used is quantitative descriptive method. The results of the study showed that the Health Office in Temanggung Regency had already realized the direct expenditure budget and reported in accordance with PP No. 71 of 2010.
\end{abstract}

Keywords: Direct expenditure, Budget, Financial Statement, Government, Local Expenditure.

\section{PENDAHULUAN}

Pendanaan daerah merupakan suatu hal penting yang dibutuhkan oleh pemerintah untuk pembelanjaan daerah guna membiayai berbagai pengeluaran guna pembangunan daerah. Belanja daerah dipergunakan untuk mendanai pembiayaan pemerintahan yang menjadi kewenangan provinsi atau kabupaten/kota yang terdiri dari urusan wajib, urusan pilihan dan urusan yang penanganannya dalam bagian atau bidang tertentu yang dapat dilaksanakan bersama antara pemerintah dan pemerintah daerah atau antar pemerintah daerah yang ditetapkan dengan ketentuan perundang-undangan (Permendagri 13 Tahun 2006). Belanja Daerah dibagi menjadi dua yaitu (1) Belanja Langsung, dan (2) Belanja Tidak langsung. Dalam Peraturan Menteri Dalam Negeri 13 Tahun 2006 Pasal 36 ayat (2) Belanja langsung merupakan belanja yang dianggarkan terkait secara langsung dengan pelaksanaan program dan kegiatan. Dalam Permendagri 13 Tahun 2006 belanja langsung terbagi menjadi: belanja pegawai, belanja barang dan jasa dan belanja modal.

Pada Dinas Kesehatan Kabupaten Temanggung memiliki pusat biaya karena ruang lingkup kegiatannya mencakup pelayanan kesehatan masyarakat. Hal ini direfleksikan dengan adanya program-program yang dijalankan seperti, pengelolahan rumah sakit dan puskesmas, penanggulangan penyakit dan penyuluhan kesehatan. Pengendalian keuangan sangatlah penting dilakukan oleh Dinas Kesehatan Kabupaten Temanggung supaya anggaran yang ditetapkan dapat membiayai semua kebutuhan program yang dijalankan serta realisasinya dapat sesuai dengan anggaran dan program kerja yang ditetapkan. 
Faridatul Jazilah, Endang Kartini Panggiarti | Analisis Belanja Langsung dan Pelaporannya ...

Pada Peraturan Pemerintah No. 71 Tahun 2010 tentang Standar Akuntansi Pemerintahan (SAP) menyatakan bahwa Satuan Kerja Pelaksana Daerah (selanjutnya disingkat SKPD) dituntut untuk dapat melaporkan keuangannya dengan baik dan benar sesuai dengan ketentuan yang berlaku. Dalam pengendalian keuangan yang dilakukan oleh Dinas Kesehatan Kabupaten Temanggung menggunakan laporan keuangan yang disusun oleh Dinas Kesehatan Kabupaten Temanggung sebagai ukuran atas pengendalian keuangan sesuai dengan SAP pada Peraturan Pemerintah No. 71 Tahun 2010. Laporan keuangan inilah yang merupakan hasil akhir dari proses akuntansi yang dilakukan oleh pemerintah daerah. Laporan keuangan inilah yang kemudian dijadikan salah satu bentuk pertanggungjawaban penyelenggaraan pemerintah daerah yang digunakan oleh pihak luar (DPRD dan masyarakat) dalam mengambil keputusan dan menilai penyelenggaraan pemerintah daerah.

Belanja langsung merupakan bagian dari belanja daerah yang pelaksanaannya harus sesuai dengan peraturan yang ada. Kabupaten Temanggung adalah salah satu kabupaten di eks karesidenan Kedu dan kebetulan daerah ini merupakan daerah agraris yang agak jauh dari daerah perkotaan yaitu terletak di perbatasan dengan Kabupaten Kendal (di utara), Kabupaten Semarang (di timur), Kabupaten Semarang (di selatan), serta Kabupaten Wonosobo (di barat). Jumlah penduduk Kabupaten ini per tahun 2017 mencapai 759.128 jiwa (Wikipedia.com).

Berdasarkan uraian diatas maka peneliti ingin meneliti dan mengkaji lebih jauh tentang belanja langsung dan pelaporannya pada Dinas Kesehatan Kabupaten Temanggung. Apakah telah sesuai dengan peraturan yang berlaku dan Standar Akuntansi Pemerintahan yang telah ditetapkan oleh pemerintah. Hasil penelitian ini diharapkan dapat memberikan kontribusi bahwa Dinas Kesehatan Kabupaten Temanggung telah menerapkan pengendalian keuangan seperti SAP yang ditetapkan dan dapat dijadikan referensi yang baik untuk pengendalian keuangan dan perbandingan pengendalian keuangan pada daerah lain pada unit yang sama yaitu Dinas Kesehatan.

\section{TINJAUAN PUSTAKA}

\section{Peraturan Pemerintah No. 71 Tahun 2010 tentang Standar Akuntansi Pemerintah}

Peraturan Pemerintah Nomor 71 Tahun 2010 menjelaskan Standar Akuntansi Pemerintahan (selanjutnya disebut SAP) adalah prinsip - prinsip akuntansi yang diterapkan dalam menyusun dan menyajikan laporan keuangan pemerintah. Penerapan Peraturan Pemerintah Nomor 24 Tahun 2005 masih bersifat sementara sebagaimana diamanatkan dalam Pasal 36 ayat (1) Undang-Undang Nomor 17 Tahun 2003 tentang Keuangan Negara yang menyatakan bahwa selama pengakuan dan pengukuran pendapatan dan belanja berbasis akrual belum dilaksanakan, digunakan pengakuan dan pengukuran berbasis kas. Peraturan Pemerintah ini digunakan sebagai acuan dan dasar bagi dinas-dinas di lingkungan Kabupaten Temanggung untuk melakukan pengendalian keuangan. Pelaporan dan pertanggung jawaban diperlukan sebagai bentuk kinerja kepala dinas masing-masing SKPD kepada kepala daerah atau Bupati di Kabupaten Temanggung. 
Faridatul Jazilah, Endang Kartini Panggiarti | Analisis Belanja Langsung dan Pelaporannya ...

PP No. 71 Tahun 2010 tentang Standar Akuntansi Pemerintahan, laporan keuangan disusun untuk menyediakan informasi yang relevan mengenai posisi keuangan dan seluruh transaksi yang dilakukan oleh suatu entitas pelaporan selama satu periode pelaporan. PP No. 71 Tahun 2010 tentang Standar Akuntansi Pemerintahan dalam penyusunan laporan keuangan meliputi:

1. Laporan Realisasi Anggaran

2. Neraca

3. Laporan Operasional (LO)

4. Laporan Arus Kas (LAK)

5. Laporan Perubahan Ekuitas (LPE)

6. Catatan atas Laporan Keuangan (CaLK).

Landasan Hukum penyusunan Laporan keuangan harus menunjukan ketaatan terhadap peraturan Perundang-undangan antara lain :

1. Peraturan Pemerintah Nomor 71 tahun 2010 tentang Standar Akuntansi Pemerintah

2. Peraturan Pemerintah Nomor 58 tahun 2005 tentang pengelolahan Keuangan daerah.

3. Peraturan Pemerintah Nomor 08 tahun 2006 tentang Laporan Keuangan dan Kinerja Instansi Pemerintah.

4. Peraturan Menteri Dalam Negeri Nomor 13 tahun 2006 tentang Pedoman Pengelolaan Keuangan Daerah.

5. Peraturan Menteri Dalam Negeri Nomor 59 tahun 2007 tentang Peraturan Pemerintah Nomor 13 Tahun 2006.

6. Peraturan Menteri Dalam Negeri No. 21 Tahun 2010 tentang perubahan atas peraturan Menteri Dalam Negeri No.13 Tahun 2006 Tentang Pedoman Pengelolaan Kuangan Daerah.

Sesuai dengan SAP yang tercantum dalam lampiran Peraturan Pemerintah Nomor 71 Tahun 2010 yaitu SAP berbasis akrual dan SAP berbasis kas menuju akrual. Pemerintah menerapkan SAP berbasis akrual yaitu SAP yang mengakui beban, aset, utang dan ekuitas dalam pelaporan finansial berbasis akrual, serta mengakui pendapatan, belanja, dan pembiayaan dalam pelaporan pelaksanaan anggaran berdasarkan basis yang ditetapkan dalam APBN/APBD. SAP berbasis akrual tersebut dinyatakan dalam bentuk PSAP dan dilengkapi dengan Kerangka Konseptual Akuntansi Pemerintahan, yaitu dengan pelayanan publik serta nomor rekening perkiraan yang digunakan. Sedangkan untuk SAP berbasis kas menuju akrual dilaksanakan secara bertahap dari SAP berbasis kas menju akrual menjadi penerapan SAP berbasis akrual. SAP berbasis kas menju akrual yaitu SAP yang mengakui pendapatan, belanja, dan pembiayaan berbasis kas, serta mengakui aset, utang dan ekuitas dana berbasis akrual (Singkali dan Widuri, 2014). Seperti penelitian yang dilakukan oleh Singkali dan Widuri yang mengkaji tentang penerapan standar akuntansi pemerintah pada Dinas Pendapatan dan Pengelolaan Keuangan Aset Daerah (DPPKAD) 
Faridatul Jazilah, Endang Kartini Panggiarti | Analisis Belanja Langsung dan Pelaporannya ...

Kabupaten Toraja Utara yang melakukan evaluasi terhadap pengakuan, pengukuran, pengungkapan, dan penyajian atas pendapatan, belanja dan pembiayaan sudah sesuai dengan SAP yang berlaku.

Pada pemerintah provinsi Banten juga menunjukkan hasil yang positif antara penerapan SAP dengan kualitas laporan keuangan (Mahardini dan Miranti, 2015). Pada Badan Lingkungan Hidup Provinsi Sumatera Utara penerapan SAP juga memberikan kualitas informasi pada laporan keuangan terutama menggunakan basis akrual dan memberikan informasi kinerja yang baik untuk pemerintah (Lubis, 2017). Pada Dinas Pendapatan Pengelolaan Keuangan dan Aset Daerah (DPPKAD) Kabupaten Gorontalo juga memberikan hasil yang positif tentang penerapan standar akuntansi pemerintah dengan kualitas laporan keuangannya (Sako dan Lantowa, 2018). Penelitian selanjutnya tentang penerapan standar akuntansi yang memberikan pengaruh langsung terhadap kualitas laporan keuangan yaitu penelitian Nugraeni dan Budiantara (2015) pada SKPD di pemerintahan Yogyakarta.

\section{Belanja Daerah}

Pengertian belanja menurut PSAP No.2 (Erlina, 2008) adalah semua pengeluaran dari rekening kas umum Negara/Daerah yang mengurangi saldo anggaran lebih dalam periode tahun anggaran bersangkutan yang tidak akan diperoleh pembayarannya kembali oleh pemerintah. Sedangkan menurut Peraturan Menteri Dalam Negeri Nomor 21 Tahun 2011 tentang belanja daerah didefenisikan sebagai kewajiban pemerintah daerah yang diakui sebagai pengurang nilai kekayaan bersih. Istilah belanja terdapat dalam laporan realisasi anggaran, karena dalam penyusunan laporan realisasi anggaran masih menggunakan basis kas. Belanja diklasifikasikan menurut klasifikasi ekonomi (jenis belanja), oganisasi dan fungsi. Klasifikasi ekonomi adalah pengelompokkan belanja yang didasarkan pada jenis belanja untuk melaksanakan suatu aktifitas.

\section{Belanja Langsung}

Belanja langsung merupakan belanja yang terkait langsung dengan produktivitas kegiatan atau terkait langsung dengan tujuan organisasi (Mursyidi, 2013). Belanja pelayanan langsung adalah belanja yang manfaatnya dapat dinikmati secara langsung oleh masyarakat. Belanja langsung merupakan belanja yang berupa investasi fisik (pembangunan infrastruktur) yang mempunyai nilai ekonomis yang lebih dari satu tahun dan mengakibatkan terjadinya penambahan aset daerah. Belanja langsung adalah belanja yang mempengaruhi secara langsung oleh adanya program dan kegiatan yang direncanakan. Pemerintah diminta lebih fokus meningkatkan belanja langsung (direct spending), baik melalui peningkatan daya beli konsumen maupun pembangunan infrastruktur.

Sedangkan menurut Mahmudi (2010) yang mengemukakan bahwa belanja langsung yaitu biaya yang langsung terkait dengan kegiatan. Artinya suatu kegiatan tidak akan terlaksana tanpa biaya tersebut. Contohnya, biaya alat tulis kantor, biaya bahan/material, pembelian peralatan, mesin, kendaraan. 
Faridatul Jazilah, Endang Kartini Panggiarti | Analisis Belanja Langsung dan Pelaporannya ...

Untuk pemerintah daerah berdasarkan Peraturan Pemerintah No.58 tahun 2005 yang kemudian dijabarkan dalam Peraturan Menteri Dalam Negeri No. 13 tahun 2006 belanja langsung dari suatu kegiatan dibagi menurut jenis belanja yang terdiri dari:

\section{Belanja Modal}

Belanja modal adalah pengeluaran yang dilakukan dalam rangka pembelian/ pengadaan atau pembangunan aset tetap berwujud yang mempunyai nilai manfaat lebih dari 12 (duabelas) bulan untuk digunakan dalam kegiatan pemerintahan, seperti dalam bentuk tanah, peralatan dan mesin, gedung dan bangunan, jalan, irigasi dan jaringan dan aset tetap lainnya. Nilai pembelian/pengadaan atau pembangunan aset tetap berwujud yang dianggarkan dalam belanja modal hanya sebesar harga beli/bangun aset (Mursyidi, 2013:300). Sesuai dengan Standar Akuntansi Pemerintah (SAP), belanja modal dibagi dalam 5 kategori, di antaranya:

a. Belanja modal tanah

Belanja modal tanah adalah pengeluaran atau biaya yang digunakan untuk pengadaan/pembelian/pembebasan, penyelesaian, balik nama dan sewa tanah pengosongan, pengurugan, perataan,pematangan tanah,pembuat sertifikat, dan pengeluaran lainnya sehubungan dengan perolehan hak atas tanah dan sampai tanah dimaksud dalam kondisi siap pakai.

b. Belanja modal peralatan dan mesin

Belanja modal peralatan dan mesin adalah pengeluaran atau biaya yang digunakan untuk pengadaan/penambahan/penggantian dan peningkatan kapasitas peralatan dan mesin, serta inventaris kantor yang memberikan manfaat lebih dari 12 bulan, dan sampai peralatan dan mesin dimaksud dalam kondisi siap pakai.

c. Belanja modal gedung dan bangunan

Belanja modal gedung dan bangunan adalah pengeluaran atau biaya yang digunakan untuk pengadaan/penambahan/penggantian dan termasuk pengeluaran untuk perencanaan, pengawasan, dan pengelolaan pembangunan gedung dan bangunan yang menambah kapasitas sampai gedung dan bangunan dimaksud dalam kondisi siap pakai.

d. Belanja jalan, irigasi, dan jaringan

Belanja modal jalan, irigasi, dan jaringan adalah pengeluaran atau biaya yang digunakan untuk pengadaan/penambahan/penggantian/peningkatan/ pembangunan /pembuatan serta perawatan dan termasuk pengeluaran untuk perencanaan, pengawasan dan pengelolaan jalan irigasi dan jaringan yang menambah kapasitas sampai jalan irigasi dan jaringan dimaksud dalam kondisi siap pakai.

e. Belanja modal fisik lainnya

Belanja modal fisik lainnya adalah pengeluaran atau biaya yang digunakan untuk pengadaan/penambahan/penggantian/peningkatan pembangunan atau 
Faridatul Jazilah, Endang Kartini Panggiarti | Analisis Belanja Langsung dan Pelaporannya ...

pembuatan serta perawatan terhadap fisik lainnya yang tidak dapat dikategorikan ke dalam kriteria belanja modal tanah, peralatan dan mesin, gedung dan bangunan dan jalan irigasi dan jaringan. Termasuk dalam belanja ini adalah belanja modal kontrak sewa beli, pembelian barang-barang kesenian, barang purbakala, dan barang untuk museum, hewan ternak dan tanaman, buku-buku, dan jurnal ilmiah.

\section{Belanja Barang dan Jasa}

Belanja barang dan jasa adalah pengeluaran pembelian/pengadaan barang yang nilai manfaatnya kurang dari 12 (dua belas) bulan dan/atau pemakaian jasa dalam melaksanakan program dan kegiatan pemerintahan daerah. Belanja barang dan jasa ini mencakup belanja barang pakai habis, bahan/material, jasa kantor, premi asuransi, perawatan kendaraan bermotor, cetak/penggandaan, sewa rumah / gedung/gudang/ parkir, sewa sarana mobilitas, sewa alat berat, sewa perlengkapan dan peralatan kantor, makanan dan minuman, pakaian dinas dan atributnya, pakaian kerja, pakaian khusus dan hari- hari tertentu, perjalanan dinas, perjalanan dinas pindah tugas, dan pemulangan pegawai. Berikut klasifikasinya yaitu belanja bahan pakai habis, belanja bahan/material, belanja jasa kantor, belanja premi asuransi, belanja perawatan kendaraan bermotor, belanja cetak dan pengadaan, belanja sewa rumah/gedung/gudang/parkir, belanja sewa sarana mobilitas, belanja sewa alat berat, elanja sewa perlengkapan dan peralatan kantor, belanja makanan dan minuman, belanja pakaian dinas dan atributnya, belanja pakaian kerja, belanja pakaian khusus dan hari-hari tertentu, belanja perjalanan dinas, belanja perjalanan pindah tugas, belanja pemulangan pegawai, belanja pemeliharaan, belanja jasa konsultasi, belanja barang untuk diserahkan kepada masyarakat/pihak ketiga, belanja barang untuk dijual kepada masyarakat/pihak ketiga, belanja beasiswa pendidikan PNS, belanja kursus, pelatihan, sosialiasi, dan bimbingan teknis PNS, belanja honorarium non pegawai, belanja honorarium PNS, belanja honorarium non PNS, dan belanja uang untuk diberikan kepada pihak ketiga/masyarakat.

Terkait dengan penelitian-penelitian terdahulu tentang belanja langsung dan tidak langsung ini yaitu pada penelitian Kristiyanto dan Widodo (2017) menyatakan bahwa penerapan belanja langsung dan tidak langsung menunjukkan hasil yang lebih efisien untuk mengurangi kemiskinan di pemerintah-pemerintah Kabupaten Kota di Jawa Timur. Pada penelitian ini, peneliti lebih menekankan pada analisis belanja langsung dan kesesuaian pelaporannya berdasarkan SAP di Dinas Kesehatan Kabupaten Temanggung.

\section{METODE PENELITIAN}

\section{Rancangan Penelitian, Ruang Lingkup atau Obyek, Tempat}

Penelitian ini menggunakan pendekatan kualitatif, yaitu menjelaskan tentang prosedur dan mekanisme belanja bahan dan pelaporannya pada Dinas Kesehatan di Kabupaten Temanggung. Jenis data yang diperoleh berupa data sekunder yaitu angka Laporan Keuangan pada Dinas Kesehatan Kabupaten Temanggung dan melakukan wawancara dengan pihak-pihak terkait tentang pelaporan laporan keuangannya. 
Faridatul Jazilah, Endang Kartini Panggiarti | Analisis Belanja Langsung dan Pelaporannya ...

\section{Teknik Pengumpulan Data, dan Teknik Analisa Data}

Metode yang dipakai penelitian ini adalah metode diskriptif dengan cara mengumpulkan dan mengklasifikasikan data yang di peroleh dari Dinas Kesehatan Kabupaten Temanggung dan membandingkan pelaporan keuangan Dinas Kesehatan Kabupaten Temanggung dengan Peraturan Pemerintah No. 71 Tahun 2010 tentang Standar Akuntansi Pemerintah apakah sudah sesuai atau tidak dengan peraturan yang berlaku tersebut.

Teknik analisis data yang digunakan pada penelitian ini adalah diskriptif kualitatif yaitu menjelaskan tentang penerapan Standar Akuntansi Pemerintah khususnya pada belanja langsung kesesuaiannya dengan Peraturan Pemerintah yang berlaku.

\section{HASIL DAN PEMBAHASAN}

\section{Jenis Belanja Langsung di Dinas Kesehatan Kabupaten Temanggung}

Dinas Kesehatan Kabupaten Temanggung merupakan salah satu SKPD Pemerintah Kabupaten Temanggung yang bertanggung jawab dalam melaksanakan program pembangunan kesehatan di Kabupaten Temanggung dan melaksanakan kewenangan otonomi daerah dalam rangka pelaksanaan tugas sesuai desentralisasi di bidang kesehatan. Terdapat tiga jenis belanja langsung yang diberlakukan di Dinas Kesehatan Kabupaten Temanggung yaitu belanja jasa kantor, belanja jasa service, dan belanja peralatan kebersihan dan bahan pembersih. Belanja langsung jasa kantor adalah peralatan keperluan kantor. Belanja langsung jasa service untuk service kendaraan mobil dinas dan motor dinas. Sedangkan belanja peralatan kebersihan dan bahan pembersih berupa lap pel, sapu, pembersih lantai dan ember. Adapun klasifikasi belanja langsung dalam laporan realisasi anggaran tahun 2017-2019 adalah sebagai berikut:

Tabel 1. Klasifikasi belanja langsung dalam Laporan Realisasi Anggaran tahun 2017 2019

\begin{tabular}{lcccccc}
\hline \multirow{2}{*}{ Akun } & \multicolumn{2}{c}{ Tahun 2017} & \multicolumn{2}{c}{ Tahun 2018} & \multicolumn{2}{c}{ Tahun 2019} \\
& Angka & Persentase & Angka & Persentase & Angka & Persentase \\
\hline $\begin{array}{l}\text { Belanja } \\
\text { jasa kantor }\end{array}$ & 84.150 .000 & $98,61 \%$ & 160.000 .000 & $73,03 \%$ & 75.000 .000 & $66,59 \%$ \\
$\begin{array}{l}\text { Belanja } \\
\text { jasa service }\end{array}$ & 4.400 .000 & $78,48 \%$ & 4.500 .000 & $99,73 \%$ & 669.000 & $97,16 \%$ \\
$\begin{array}{l}\text { Belanja } \\
\text { peralatan } \\
\text { kebersihan } \\
\text { dan bahan } \\
\text { pembersih }\end{array}$ & 5.340 .000 & $96,84 \%$ & 6.280 .000 & $63,46 \%$ & & \\
\hline
\end{tabular}


Faridatul Jazilah, Endang Kartini Panggiarti | Analisis Belanja Langsung dan Pelaporannya ...

Grafik

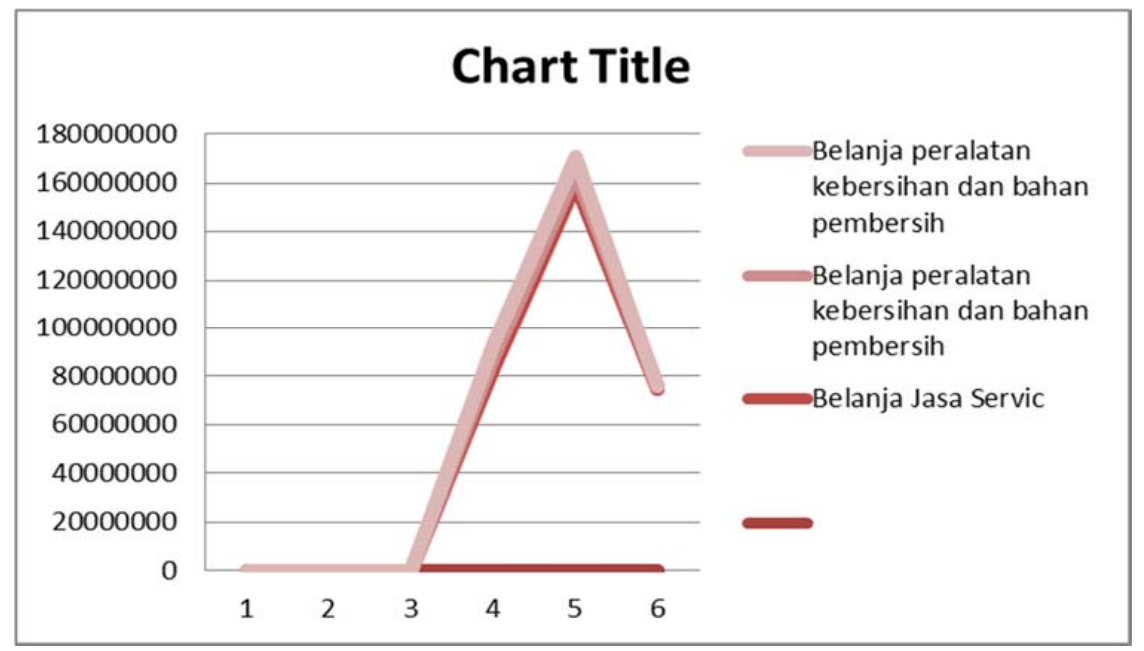

Dapat disimpulkan dari grafik diatas Belanja jasa kantor dari 2017 sebesar 98,61\% dan di 2018 mengalami penurunan sebesar 73,03\% dan 2019 mengalami penuruanan juga sebesar 66,59\%, dan Belanja jasa service tahun 2017 sebesar 78,48\%, Tahun 2018 menaglami peningkatan sebesar 99,73\% , dan 2019 mengalami penurunan 97,16\% , dan Belanja Peralatan kebersihan dan bahan pembersih dari 2017-2019 mengalami penurunan yang drastis dan di tahun 2019 tidak ada perbelanjaan. Jadi klasifikasi belanja langsung di Dinas Kesehatan Kabupaten Temanggung per tahunnya kurang stabil.

Tabel 2. Perbandingan Hasil Realisasi Anggaran Belanja dan Belanja Langsung

\begin{tabular}{|c|c|c|c|}
\hline Akun & $\begin{array}{c}\text { Realisasi Anggaran } \\
\text { Belanja }\end{array}$ & Belanja Langsung & Rasio \\
\hline (1) & $(2)$ & (3) & (3) : (4) \\
\hline Tahun 2017 & 46.749.633.113 & 52.454 .930 .550 & 1.1220394055972 \\
\hline Tahun 2018 & 36.097 .658 .240 & 39.384.914.630 & 1.0910656411045 \\
\hline Tahun 2019 & 54.778 .965 .927 & 61.785 .350 .708 & 1.1279028302640 \\
\hline
\end{tabular}

Dari tabel diatas dapat di simpulkan dari tahun 2017, 2018, dan 2019 untuk realisasi anggaran belanja lebih kecil dari belanja langsung dengan demikian penyerapan anggaran belanja lebih banyak di belanja langsung nya.

\section{Pelaporan Belanja Langsung dan Kesesuaiannya dengan SAP}

Standar Akuntansi Pemerintah adalah peraturan yang wajib diikuti dan dipedomani oleh seluruh SKPD di Indonesia terutama di Dinas Kesehatan Kabupaten Temanggung. Peneliti ingin membandingkan apakah pelaporan laporan keuangan yang disusun oleh Dinas Kesehatan Kabupaten Temanggung telah sesuai dengan Peraturan Pemerintah No. 
Faridatul Jazilah, Endang Kartini Panggiarti | Analisis Belanja Langsung dan Pelaporannya ...

71 Tahun 2010 tentang Standar Akuntansi Pemerintah. Tabel berikut ini menyajikan perbandingan pelaporan keuangan dari Dinas Kesehatan Kabupaten Temanggung dan PP No. 71 Tahun 2010 sebagai berikut:

Tabel 3. Perbandingkan Jenis Pelaporan Keuangan menurut Dinas Kesehatan Kabupaten Temanggung dengan PP No. 71 Tahun 2010

\begin{tabular}{llcc}
\hline \multirow{2}{*}{ No } & \multicolumn{1}{c}{ Jenis Pelaporan Keuangan } & $\begin{array}{c}\text { Sesuai PP No. 71 } \\
\text { Tahun 2010 }\end{array}$ & $\begin{array}{c}\text { Dinas Kesehatan } \\
\text { Kab. Temanggung }\end{array}$ \\
\hline 1 & Laporan Realisasi Anggaran & $\sqrt{ }$ & $\sqrt{ }$ \\
2 & Neraca & $\sqrt{ }$ & $\sqrt{ }$ \\
3 & Laporan Operasional (LO) & $\sqrt{ }$ & - \\
4 & Laporan Arus Kas (LAK) & $\sqrt{ }$ & $\sqrt{ }$ \\
5 & Laporan Perubahan Ekuitas (LPE) & $\sqrt{ }$ & $\sqrt{ }$ \\
\multirow{2}{*}{6} & Catatan atas Laporan Keuangan & $\sqrt{ }$ & (CaLK) \\
\hline
\end{tabular}

Berdasarkan tabel diatas, dapat dilihat bahwa Dinas Kesehatan Kabupaten Temanggung tidak mempunyai salah satu komponen dalam penyusunan laporan keuangan yaitu komponen laporan arus kas. Laporan arus kas tidak dimasukkan karena tidak melakukan fungsi perbendaharaan. Komponen laporan keuangan yang ada didalam PP No. 71 Tahun 2010 tentang SAP belum sepenuhnya diberlakukan atau pemberlakuannya masih 83\% karena Laporan Arus Kas tidak ada. Dinas kesehatan Kabupaten Temanggung sudah menggunakan SAP berbasis Akrual.

\section{Analisis Belanja Langsung}

Berdasarkan hasil penelitian diatas telah diketahui bahwa Dinas Kesehatan Temanggung sudah melaksanakan belanja langsung yang berupa barang dan jasa seperti belanja jasa service. Belanja jasa service tersebut digunakan untuk mereparasi kendaraan yang dimiliki oleh Dinas Kesehatan guna menambah kapasitas nilai aset tersebut. Pada Tahun 2018 realisasi anggaran belanja langsung Dinas Kesehatan berjumlah Rp 36.097.658.240 sedangkan Pada Tahun 2019 berjumlah Rp 54.778.965.927 yang artinya jumlah total realisasi anggaran belanja langsung Dinas Kesehatan mengalami peningkatan.

PP No. 71 Tahun 2010 tentang Standar Akuntansi Pemerintahan, Laporan keuangan disusun untuk menyediakan informasi yang relevan mengenai posisi keuangan dan seluruh transaksi yang dilakukan oleh suatu entitas pelaporan selama satu periode pelaporan. Sesuai dengan hasil penelitian yang peneliti lakukan yaitu dalam pelaporan keuangan Dinas Kesehatan Kabupaten Temanggung sudah melaksanakan sesuai dengan peraturan pemerintah. Namun ada salah satu komponennya dalam penyusunan laporan keuangan yang tidak ada atau tidak sesuai dengan PP No. 71 Tahun 2010 yaitu komponen laporan arus kas. Pada Dinas Kesehatan Kabupaten Temanggung sebagai entitas akuntansi publik tidak diwajibkan menyusun laporan arus kas kecuali SKPKD (Satuan Kerja 
Faridatul Jazilah, Endang Kartini Panggiarti | Analisis Belanja Langsung dan Pelaporannya ...

Pengelola Keuangan Daerah) sebagai entitas pelaporan yang wajib menyusun laporan arus kas. Karena di dalam Peraturan Menteri Kesehatan Republik Indonesia Nomor 39 Tahun 2019 Dinas Kesehatan merupakan SKPD bukan BLU dan di dalam SKPD tidak adanya Laporan Arus Kas tidak seperti pukesmas, rumah sakit yang sudah BLU.

\section{KESIMPULAN}

Adapun simpulan yang dapat diambil dari penelitian di atas adalah sebagai berikut:

1. Dapat disimpulkan belanja langsung lebih besar dari realisasi anggaran belanja

2. Dinas Kesehatan Kabupaten Temanggung sudah menggunakan SAP berbasis Akrual

3. Dinas Kesehatan Kabupaten Temanggung sudah menerapkan Pelaporan keuangan sesuai dengan PP No. 71 Tahun 2010 namun Laporan Arus Kasnya belum diterapkan karena tidak melakukan fungsi perbendaharaan SKPKD. Sehingga Dinas Kesehatan Kabupaten Temanggung ini baru menerapkan 83\% dari SAP sesuai dengan PP No. 71 Tahun 2010.

\section{KETERBATASAN DAN SARAN}

Adapun keterbatasan penelitian ini adalah:

1. Penelitian ini menggunakan metode kualitatif sehingga tidak dilakukan penelitian mendalam secara kuantitatif untuk melihat adanya hubungan atau pengaruh dari berbagai variable yang mungkin ada.

Adapun saran penelitian ini adalah:

1. Untuk Anggaran berikutnya Dinas Kesehatan Kabupaten Temanggung dalam pengelolaan Keuangan Daerah yang benar-benar efektif dapat terwujud dan Laporan Keuangan yang disajikan dapat berguna bagi para pengguna laporan tersebut.

2. Untuk penelitian selanjutnya yang mengambil penelitian yang berjudul serupaatau mengambil objekpenelitian yang sama untuk dapat menyempurnakan penulisan ini menjadi lebih baik.

\section{DAFTAR PUSTAKA}

Mawikere L, M. J. (2015). Analisis Sistem Pelaporan Belanja Langsung Tahun 2013 Pada Badan Pengelola Keuangan dan Barang Milik Daerah Provinsi Sulawesi Utara . Diambil kembali dari Jurnal Emba.

Nadiya, E. (2018). Analisis Pencatatan dan Pelaporan Belanja Modal Pada Teknis Dinas Pusat Pengembangan Mutu Guru. Diambil kembali dari journals.stiedwisakti.ac.id.

Tampanatu, A. (2013). Analisis Pencatatan dan Pelaporan Belanja Langsung Pada SKPD Di Kota Bitung . Diambil kembali dari Jurnal Emba.

Yanti Silvia watuseke, J. (2014). Analisis Belanja Modal dan Pelaporannya Pada Dinas Kesehatan Kota Manado. Diambil kembali dari ejournal.unsrat.ac.id. 